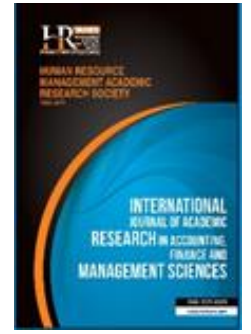

International Journal of Academic Research in Accounting, Finance and Management Sciences

Vol. 9, No.1, January 2019, pp. 105-110

E-ISSN: 2225-8329, P-ISSN: 2308-0337

(C) 2018 HRMARS

www.hrmars.com

To cite this article: Tarmidi, D. (2019). Tax Compliance and Uncompliance Entity: A Comparative Study of Investor Reaction, International Journal of Academic Research in Accounting, Finance and Management Sciences 9 (1): 105 110.

http://dx.doi.org/10.6007/IJARAFMS/v9-i1/5823 (DOI: 10.6007/IJARAFMS/v9-i1/5823)

\title{
Tax Compliance and Uncompliance Entity: A Comparative Study of Investor Reaction
}

\section{Deden Tarmidi}

Faculty of Economic and Business, Universitas Mercu Buana, Jl. Meruya Selatan No. 1 Jakarta E-mail: deden.tarmidi@mercubuana.ac.id (Corresponding author)

\begin{abstract}
As the theory of signals that companies will always give a positive signal so investors are interested, but what about the tax policy taken by the company whether investors react? This research was conducted to determine investor reaction to company policies to comply with tax provisions or not comply with taxation provisions. With regression and comparative analysis, using secondary data from manufacturing companies in Indonesia in 2013-2017, it is known that investors react more significantly to corporate tax non-compliance policies compared to company policies to comply. However, with a positive reaction on tax non-compliance and negative reaction on corporate tax compliance, it indicates that investors in Indonesia are more concerned with the company's short-term performance in the form of current profits compared to long-term performance in the form of future profits which are likely to be affected by tax penalties arising from tax uncompliance.

Key words

Tax Compliance, Tax Uncompliance, Investor Reaction

Received: 25 Apr 2019 (C) The Authors 2018 Direct link to the article (The weblink will be encapsulated)

Revised: 09 May 2019 Published by Human Resource Management Academic Research Society (www.hrmars.com)

Accepted: 18 May 2019 This article is published under the Creative Commons Attribution (CC BY 4.0) license. Anyone may reproduce, distribute, translate and create derivative works of this article (for both commercial and non-commercial purposes), subject to full attribution to the original publication and authors. The full terms of this license may be seen at: http://creativecommons.org/licences/by/4.0/legalcode
\end{abstract}

\section{Introduction}

For profit-oriented companies, tax is a burden that will reduce profits that have an impact on a number of things behind it. For investors, increasing the tax burden that reduces profits will certainly reduce the amount of dividends that will be received. But for management, increasing the tax burden that reduces profits will also reduce the performance evaluation of management in managing the company. These impacts encourage management to carry out specific policies with the aim that the amount of profit is not too eroded by the tax burden, either in a legal and tax compliance or illegal and uncompliance (tax evasion) manner, although not all entities take the policy (Ogundajo and Onakoya, 2016).

Table 1. Tax UnCompliance Case and Stock Process

\begin{tabular}{|c|c|c|c|c|c|c|c|}
\hline \multirow{2}{*}{ No. } & \multirow{2}{*}{ Corporate } & \multirow{2}{*}{ Code } & \multicolumn{5}{|c|}{ Stock Price } \\
\hline & & & & e Publication & Afte & blication & Up/Down \\
\hline 1 & PT. Coca Cola Indonesia & CCL (AUD) & $\$$ & 12,030 & $\$$ & 9,320 & $-22,53$ \\
\hline 2 & PT. Toyota Motor Manufacturing Indonesia & ASII (IDR) & $\mathrm{Rp}$ & 7.600 & $\mathrm{Rp}$ & 6.800 & 10,53 \\
\hline 3 & PT Bank Rakyat Indonesia (Persero) Tbk. & BBRI (IDR) & $\mathrm{Rp}$ & 3.640 & $\mathrm{Rp}$ & 3.660 & 0,55 \\
\hline 4 & PT Selamat Sempurna Tbk. & SMSM (IDR) & $\mathrm{Rp}$ & 1.255 & $\mathrm{Rp}$ & 1.400 & 11,55 \\
\hline
\end{tabular}


In table 1 it can be observed that companies indicated to do tax non-compliance (e.g., Coca Cola and Toyota Motor) by means of tax avoidance and published by the media, the stock price drops or are negative at the end of the year compared to the end of the year before publication. Instead the company published by the media as an obedient Taxpayer (BRI Bank and Selamat Sempurna), its stock price rises or is positive at the end of the year after media publication. But what about other company's shares? This study aims to determine investor reactions to company policies to comply with or not comply with taxes on companies listed on the Indonesia Stock Exchange.

Tax policies carried out by management are not all informed to the public and investors, even though in the end these policies certainly have an impact on investors who expect dividend receipts in the future so that investors need to analyze how the investor's attention to the policy (Ariff and Hashim, 2014).

Some studies that analyze corporate tax policy with tax planning find mixed results in company value. Appolos et al. (2016), Lestari and Wardhani (2015) found positive results of tax planning on firm value. But Salawu et al. (2017) in his study concluded that tax planning does not affect the value of the company. Likewise with research on tax avoidance against firm value. Yakovlev and Davies (2014), Mulders and Stiglingh (2008), found that tax avoidance and even tax evasion activities will ultimately harm the company as well as tax penalties that add to the company's costs in the end which reduce the value of the company (Chen et al. 2014). But Yorke et al. (2016), Anggoro and Septiani (2015) in their study found a positive effect of tax avoidance on firm value.

\section{Literature Review}

\subsection{Theoretical Framework}

\subsubsection{Signaling Theory}

Brigham and Houston (2011) explained that signal is an action taken by a company to provide code or instructions for investors about how management views the company's prospects.

Signaling theory explains how companies provide financial statement information to external parties with certain motivations. The company's encouragement to provide information is because there is information asymmetry between the company and outside parties so that publicity is needed about the condition of the company in order to create a good image of the company and outsiders will be interested in joining as investors in projects undertaken by the company. Lack of information for outsiders about the company causes them to protect themselves by providing low prices for the company. Companies can increase company value by reducing information asymmetry. One way to reduce information asymmetry is to give signals to outsiders, the more the number of investors especially company then the entity will be more careful in each policy taken. Pernamasari (2018) explained that institutional ownership have positive impact on voluntary disclosure, moreover mandatory disclosure like tax reporting.

Signals that are accepted by the public are reflected in the ups and downs of the entity's stock price which is the reaction of investors (Keown, 2005). So the stock price before and after the publication of the company's financial statements is used as the basis for analyzing how investors react to the tax policies of the entity.

\subsubsection{Tax Compliance Theory}

Devos (2012) explains the Theory of Tax Compliance which is divided into two approaches, namely: 1) Economic deterrence approach and 2) Psychological approach. Where in the economic deterrence approach an approach is taken by considering external factors such as taxation information and systems, tax deductions by other parties, tax penalties, possible tax audits, and tax rates. While the psychological approach is carried out by considering the factors of individual taxpayers or employees of corporate taxpayers related to corporate taxation activities.

This study analyzes tax compliance with an economic deterrence approach, where it will be analyzed about tax policies taken by the entity whether it is obedient or not to tax provisions and how investors react to the policy. The policies taken by the company in connection with tax compliance are represented by tax planning whereas in relation to tax non-compliance represented by tax avoidance. Although both are company policies to minimize the future tax burden (Ayers et al., 2009), tax planning is carried out without violating the applicable rules while tax avoidance is done by violating existing tax rules. 


\subsection{Conceptual Framework and Hypothesis Development}

\subsubsection{Tax Compliance on Investor Reaction}

Some research on tax planning in its effect on firm value has different conclusions. As is known that the purpose of tax planning is to minimize the tax burden and increase profits but still within the corridor of tax compliance, investors should respond positively to this by buying shares that result in the company's value rising. But the theory is not always in line, Salawu et al. (2017) in his research found that tax planning has no influence on company value, even Wahab and Holland (2012) concluded that tax planning has a negative relationship with firm value.

But the results of these studies are very contrary to the research of Pradnyana and Noviari (2017), Appolos et al. (2016), Assidi et al. (2016), Lestari and Wardhani (2015), Ling and Wahab (2018), Ogundajo and Onakoya (2016), and Graham et al. (2014) who found the results that the company policy to keep doing tax compliance by means of tax planning got a positive reaction from investors by buying shares and had an impact on increasing the firm value.

H1. Investors react to tax compliance

\subsubsection{Tax Uncompliance on Investor Reaction}

Even though it has the same goal to minimize the tax burden and increase profits, but with tax noncompliance measures, investors will give a negative reaction because they know the risk of tax penalties that will reduce profits in the future so that company profits fall (Chen et al., 2000). But not all investors are aware of the tax non-compliance policy because the entity tends to hide it (Ayers et al., 2009), so that it does not give any reaction or even give a positive reaction because it only sees increased profits, the company value increases (Yorke et al., 2016 ; Anggoro and Septiani, 2015; Nugroho and Agustia, 2017.

H2. Investors react to tax uncompliance

\subsubsection{Difference of Investor Reaction to Tax Compliance and Uncompliance}

Differences in tax policies taken by the entity between tax compliance and tax uncompliance give different reactions from the market and investors. So this study has the following hypothesis:

H3. There difference investor reaction to tax compliance and uncompliance

\section{Methodology of research}

\subsection{Population and Sample}

This study belongs to the type of causality and comparative research, wherein it will be analyzed how investors react to tax policies taken by the entity in the scope of tax compliance through tax planning and in the area of tax compliance through tax avoidance.

A total of 157 manufacturing companies listed on the Indonesia Stock Exchange were used as the population in this study with observations for 5 years (2013-2017) and purposive sampling methods in the form of completeness of data from each measurement variable studied obtained 218 panel data for analysis. From the total data, it is grouped into 2, namely 130 data on the tax compliance policy and 88 data on the policy of tax uncompliance. The secondary data obtained from the web idx.co.id and will be analyzed using the SPSS application with regression analysis and different test analysis.

\subsection{Operational Variable}

The dependent variable $(Y)$ is a variable that can be influenced by other variables, in this study which is the dependent variable is the reaction of investors. The investor's reaction to information published by the company through annual reports and financial statements is reflected in the share sale and purchase transaction which then results in closing stock prices at a certain time. Adopting the research of Hsieh (2014), investor reaction in research is measured by stock prices by reducing $\ln (\mathrm{MV} t)$ with $\ln (\mathrm{MVt}-1)$ where $\mathrm{MV}$ is stock price.

Tax compliance in this study is a company policy in minimizing the tax burden but in a way that does not conflict with tax provisions. Compliance with company tax in minimizing tax burden is seen from the large tax burden that exceeds the tax planning calculation. Whereas tax non-compliance is a company 
policy in minimizing the tax burden by illegal means. Tax compliance and tax uncompliance in this study measured by ETR adopted from in Yorke et al. (2016), Pradnyana and Noviari (2017). Tax compliance and tax uncompliance classified by looked amount of ETR, where if amount is less than 0.25 classified to tax uncompliance while if the amount is 0,25 or more classified tax compliance.

From the two groups of company policies for compliance and uncompliance, we analyzed investor reactions to these different policies and then we conducted a comparative test.

\subsection{Hypothesis Testing Method}

Classical assumption tests such as normality and heteroscedasticity tests are performed on all X data, namely ETR and Investor Reaction. After the data is declared good, then the data is split into 2 groups, namely tax compliance data and tax uncompliance data with the reaction of each investor. Then a simple regression test was carried out on each data and then a different test was carried out.

\section{Results}

\subsection{Characteristics Respondent}

In the tax compliance policy, it is known that HSMP in 2017 carried out the lowest tax compliance policy while IPOL 2017 carried out the highest tax compliance policy. Whereas the lowest tax uncompliance policy was carried out by CEKA 2017 and the highest was carried out by the TIRT 2014. Investor reaction to the lowest tax compliance company policy occurred in IGAR 2014 while the highest was at JECC 2017. The lowest investor reaction on tax uncompliance policy occurred in 2016 TIRT and highest at CPIN 2017.

\subsection{Descriptive Analysis}

Table 2. Descriptive analysis

\begin{tabular}{|l|c|c|}
\hline \multicolumn{1}{|c|}{ Variable } & Mean & Std. Deviation \\
\hline Tax Compliance & 0.27610 & 0.02604 \\
\hline Tax Uncompliance & 0.21976 & 0.02507 \\
\hline Investor Reaction to Compliance & -0.00416 & 0.02402 \\
\hline Investor Reaction to Uncompliance & 0.00131 & 0.02383 \\
\hline
\end{tabular}

Table 2 shows that the amount of means is variatively and that is good for eliminated biasness data.

\subsection{Hypothesis Test}

The classic assumption test in the form of a normality and heteroscedasticity test is carried out before testing the hypothesis in the form of a simple linear regression test and a different test. By doing the Kolmogorov-Smirnov test it is known that the Sig for Tax Policy combined is 0.109 while the Sig value for the overall investor reaction is 0.196 , with this value can be interpreted that the data is normally distributed because each $\mathrm{Sig}>0.05$. While the heteroscedasticity test shows that the coefficient value is 0.302 and greater than 0.05 which means that the data is free from the problem of heteroscedasticity.

Based on table 3, investors react to corporates' tax compliance unsignificantly that is mean Hypothesis 1 is rejected while investors react to corporations' taxes uncompliance significantly and that is mean Hypothesis 2 is accepted. These results explain that actually in Indonesia, investors are not interested in paying attention to tax policies taken by the entity. With a positive reaction to the policy of tax noncompliance and negative reaction to tax policy, it indicates that investors are more concerned with shortterm corporate performance by paying attention to current profits and not paying too much attention to long-term profits that can bear the tax burden on fines or penalties later. These results contradict the research of Pradnyana and Noviari (2017), Appolos et al. (2016), Assidi et al. (2016), Lestari and Wardhani (2015), Ling and Wahab (2018), Ogundajo and Onakoya (2016), and Graham et al. (2014) but in line with research by Wahab and Holland (2012). 
Table 3. Investors react to corporates' tax compliance

\begin{tabular}{|l|c|c|c|c|}
\hline \multicolumn{1}{|c|}{ Impact } & Prediction & P-Value & Sig & Result \\
\hline TC $>$ IRC & + & $-0,087$ & 0,287 & H1. Rejected \\
\hline TUC $>$ IRUC & - & 0,182 & $0,074^{*}$ & H2. Accepted \\
\hline IRC $\neq$ IRUC & $\neq$ & & $0,014^{* *}$ & H3. Accepted \\
\hline
\end{tabular}

$* * *$ Significant at level $10 \%, * *$ Significant at level $5 \%$, and $* * *$ Significant at level1\%

Note: $\mathrm{TC}=\mathrm{Tax}$ Compliance, $\mathrm{TUC}=\mathrm{Tax}$ Uncompliance, $\mathrm{IR}=$ Investor Reaction

In a comparative test it was found that there were differences in investor reactions to Tax Compliance and Non Tax Compliance conducted by the company, the results explained that hypothesis 3 was accepted.

\section{Conclusion}

Investors in Indonesia are more reacting to the non-tax compliance entity policy than tax compliance policies, even though investors react well to non-tax compliance activities and vice versa explain that investors pay more attention to the short-term performance of companies that do non-tax compliance with the aim of increasing profits compared vice versa.

\section{Implication and Limitation}

The results of this study are indeed frightening and should be a concern for the Government, especially the Directorate General of Taxes, to take more actions to improve corporate tax compliance, especially companies that go public. However, it may be clearer if repeat research is conducted by including the type of industry in the future study. By incorporating other policy elements, this can strengthen investors' reactions to the company.

\section{Acknowledgment}

This study supported by Research Center of Universitas Mercu Buana and the Faculty of Economic and Business, I'm grateful for the supported from Research Center team, Rector, Dean, and all lecturers were supported.

\section{References}

1. Anggoro, S. \& Septiani, A. (2015). Analisis Pengaruh Perilaku Penghindaran Pajak Terhadap Nilai Perusahaan Dengan Transparansi sebagai variabel moderating. Diponegoro Journal of Accounting, Vol. 4, No. 4, Tahun, pp. 2337-3806

2. Appolos, N., Jerry D., \& Grace O. (2016). Tax Planning and Firm Value: Empirical Evidence from Nigerian Consumer Goods Industrial Sector. Research Journal of Finance and Accounting, Vol. 7 No. 12.

3. Ariff, A. \& Hashim, M.H.A. (2014). Governance and the Value Relevance of Tax Avoidance. Malaysian Accounting Review, Vol. 13 No. 2.

4. Assidi, S., Aliana, K., \& Omri M. (2016). Tax optimization and the firm's value: evidence from the Tunisian context. Borsan Istanbul Review, 16-3, 177-184

5. Ayers, B.C., Jiang, J. \& Laplante, S.K. (2009). Taxable income as a performance measure: the effect of tax planning and earnings quality. Contemporary Accounting Research, vol. 26 no. 1, pp. 15-54

6. Chen, X., Hu, N. \& Wang, X. (2014). Tax Avoidance and Firm Value: evidence from China. Nankai Business Review International, Vol. 5 No. 1, pp. 25-42, DOI 10.1108/NBRI-10-2013-0037

7. Devos, K. (2012). The Impact of Tax Professionals upon the Compliance Behaviour of Australian Individual Tapayers. Revenue Law Journal, 22.1.2

8. Graham, JR., Hanlon, M., Shevlin, T. \& Shroff, N. (2014). Incentives for Tax Planning and Avoidance: Evidence from the Field. The Accounting Review 89, No. 3, pp. 991-1023

9. Hsieh, H.S. (2014). The causal relationship between stock returns, trading volume, and volatility. International Journal of Managerial Finance, Vol. 10 Iss. 2, pp. 218-240. 

Hall.

10. Keown, A.J., Martin, J.D, Petty, J.W. \& Scott. JR, D.F. (2005). Financial Management. Prentice

11. Lestari, N. \& Wardhani, R. (2015). The effect of the Tax Planning to Firm Value with moderating Board Diversity. International Journal of Economics and Financial Issues, 5, pp. 315-323.

12. Ling, T. \& Wahab, N. (2018). Roles of Tax Planning in market valuation of corporate social responsibility. Cogent Business \& Management, 5: 1482595.

13. Nugroho, W. \& Agustia, D. (2017). Corporate governance, tax avoidance and firm value. AFEBI Accounting Review, vol. 2 no. 2.

14. Ogundajo, G.O. \& Onakoya, A.B. (2016). Tax planning and financial performance of Nigerian manufacturing companies. International Journal of Advanced Academic Research, vol. 2, issue 7.

15. Pernamasari, R. (2018). Implementation of Good Corporate Governance and Voluntary Disclosure Compliance: 100 Compass Index Companies Listed Indonesian Stock Exhange (IDX) 2015-2016. International Journal of Academic Research in Accounting, Finance and Management Sciences 8 (2): 235249.

16. Pradnyana, I.B.G.P. \& Noviari, N. (2017). Pengaruh Perencanaan Pajak Terhadap Nilai Perusahaan Dengan Transaparansi Perusahaan sebagai Variabel Moderasi. E-Jurnal Akuntansi Universitas Udayana, Vol. 18, 2.

17. Salawu, R., Ogundipe, L. \& Yeye, O. (2017). Granger causality between corporate tax planning and firm value of Non-financial quoted companies in Nigeria. International Journal of Business and Social Science, vol. 8, no. 9.

18. Wahab, N. \& Holland, K. (2012). Tax Planning, Corporate Governance and Equity Value. The British Accounting Review, 44, 111-124

19. Yakovlev, P.A. \& Davies, D. (2014) How does the estate tax affect the number of firms?, Journal of Entrepreneurship and Public Policy, Vol. 3 Issue: 1, pp. 96-117.

20. Yorke, S., Amidu, M., \& Boateng, C. (2016). The effects of earnings management and corporate tax avoidance on firm value. International Journal of Management Practice, Vol. 9, No. 2. 